\title{
Kenyan pastoralist societies in transition: varying perceptions of the value of ecosystem services
}

\author{
$\underline{E v a ~ K a v e-Z w i e b e l}^{1}$ and Elizabeth King $^{2}$
}

\begin{abstract}
In the drylands of northern Kenya, as elsewhere in Africa, traditional pastoralist social-ecological systems are undergoing profound transformations. Diminishing resource availability, changing social values and governance systems, and new resource management institutions challenge the capacity of communities for effective common pool resource management. Individuals' values and environmental perceptions play a substantial role in decision making regarding resource use and management. Additionally, social capital within communities can influence cooperative and adaptive resource management. We studied five Laikipia Maasai communities in Kenya, which share a common natural environment, history, and political organization. We surveyed pastoralists' perceptions of the adequacy of two ecosystem services, forage availability and livestock abundance. We also assessed indicators of three forms of social capital: reciprocity, sanctioning, and norms of fairness. Four communities established set-aside conservation areas through partnership with external organizations. In those communities, we examined residents' perceptions of five different potential ecological and economic benefits from the conservation areas. We found that communities varied in residents' perceptions of grazing resource adequacy, the economic sufficiency of their livestock herds, and the benefits of conservation areas. Communities also varied in measures of social capital. We contextualize our findings in terms of the rules and conditions governing each conservation area, the roles of social capital, and the challenges of resource-use trade-offs when perceptions diverge. We conclude that taking stock of perceptions and values placed on ecosystem services is a crucial element of formulating plans for sustainable resource management and navigating trade-offs in the future.
\end{abstract}

Key Words: common pool resources; conservation; grazing; pastoralism; social capital

\section{INTRODUCTION}

Forty percent of sub-Saharan Africa is arid or semiarid rangeland. These rangelands are composed of grasslands, dry woodlands, and desert ecosystems and are home to an estimated 80 million rural pastoralists (Notenbaert et al. 2009). Traditional pastoralist systems are tightly coupled human-environment systems, in which human livelihoods are derived substantially or wholly from livestock that forage on naturally occurring rangelands. The rangeland vegetation is an ecological resource that offers both provisioning and regulating ecosystem services to pastoralists; vegetation provides fodder for livestock, and it also plays an integral role in regulating the water-soil-plant feedbacks that maintain the productive capacity of the landscape (Rietkerk et al. 2002, Ludwig et al. 2005). Historically and ecologically, livestock are also deeply embedded in the structure and function of African rangeland ecosystems, and the nutritional, economic, and cultural benefits gained from livestock can be viewed as ecosystem services, actively managed by humans. Traditional pastoralism is typically a subsistence-level production system, with families relying more on milk than meat for nutrition, selling animals to get cash for other economic needs, and building herd sizes to accrue social status, wealth, and risk buffering.

Within Africa and globally, pastoralist cultures are highly diverse, yet they tend to share key institutional and cultural adaptations that promote resilience in environments characterized by limited productivity and high resource variability (Ellis 1995). Pastoralists typically utilize extensive rangelands as common pool resources (CPRs) and manage them through customary, polycentric governance systems and social networks (Runge 1986, Ostrom 1990b, Niamir-Fuller 1998, Agrawal 2007). Mobility is a hallmark adaptation that allows pastoralists to buffer themselves against temporally variable environmental conditions and to access key resources that are heterogeneously distributed across large spatial scales (McCabe 1994). Culturally, reciprocity and sharing are salient social norms that reduce household risk exposure and promote cohesion and cooperation that support resource-use institutions (Davies and Bennett 2007). These patterns of land management, migration, and normatively prescribed social interaction achieve a resilient, adaptive fit between human resource use and the harsh and variable ecological conditions.

Today, despite their resilient social-ecological adaptations, many pastoralist systems are failing to meet households' livelihood needs and maintain ecological resources. In sub-Saharan Africa, such breakdowns in resilience are a complex legacy of the last century. Colonization, nation formation, population growth, social and economic modernization, and the imposition of statutory land tenure systems have frequently impinged on pastoralist ways of life. These factors have tended to decrease pastoralists' capacity for customary governance and grazing management and to restrict their traditional strategies for coping with disturbances such as drought (Fratkin 1997, 2001, Catley et al. 2013). Pursuing livelihood diversification and education can yield a range of choices and strategies for coping with change. However, as individuals pursue disparate goals, they may acquire different outlooks based on their experiences. The pursuit of livelihood diversification can cause social fragmentation by reducing social cohesion, social memory, and collective action within a community, three assets that are recognized as important for withstanding and adapting to changing conditions (Galvin 2008).

Social transitions have also been indirect drivers of ecological change. Land appropriation, restrictions on mobility, and increased human and livestock densities create year-round pressures on remaining rangelands, often leading to land 
degradation and further loss of grazing resources (Little 2013). In addition, climate change is now manifest in many drylands as more erratic rainfall and more frequent droughts. These changing rainfall patterns affect ecosystems directly by limiting primary productivity (Thornton et al. 2006, Kirkbride and Grahn 2008) while also exacerbating the livelihood and resource management challenges already faced by pastoralist peoples.

In response to these complex social and ecological drivers, and their feedbacks on each other, pastoralist systems are evolving. They are functioning in new environmental contexts, utilizing both traditional and alternative livelihood and land-use strategies and developing novel governance schemes (Catley et al. 2013). In many systems, the quantity, quality, or relative importance of resources, and the associated ecosystem services derived from them, are changing. This brings about a need for new or modified institutions to achieve a better fit with the characteristics of the new resource base (Steins and Edwards 1999, Cousins et al. 2007, Homann et al. 2008).

Implementing rangeland and wildlife conservation strategies can increase both the provisioning and regulation of services derived from rangelands, thereby improving pastoralists' livelihoods and long-term ecosystem health (Berkes and Turner 2006, Notenbaert et al. 2012). Indeed, today many pastoralist communities are experimenting with new land conservation strategies or are trying to revitalize former customary systems of reserve grazing (Angassa and Oba 2008, Selemani et al. 2012, Tache 2013). It cannot simply be assumed, however, that newly emerging institutions and land-use systems will in fact succeed in sustaining residents' livelihoods and the ecological processes upon which they rely. Drawing from disparate themes in current natural resource management (NRM) scholarship, we identify three issues that may influence the adoption and successful implementation of new land management institutions in the context of pastoralist communities that are transforming.

First, individuals' perceptions of the scarcity of a resource, or of the value of a key service gained from that resource, can influence their motivation to adopt or maintain new management institutions. Decision making depends on individuals' perceptions of present circumstances and the cause-and-effect relationships they expect (Kahneman 2003). As a consequence, individuals' perceptions can play a critical role in the emergence of effective resource management institutions (Adams et al. 2003). For example, people may not be motivated to adopt a conservation strategy if they do not perceive a scarcity of resources (Santos and Pacheco 2011). Or, if people do not perceive the maintenance of regulating services, e.g., healthy vegetation, as valuable for future provisioning benefits, e.g., livestock production, there is little incentive to actively manage resources (Baars and Aptidon 2002, Baird et al. 2009).

Second, when multiple ecosystem services are rendered by a given ecological resource, people are likely to assign different relative values to the multiple services. The result is likely to be diverse preferences for land use, which will affect management decisions (Lamarque et al. 2011). In the case of pastoralist societies in transition, rangeland conservation may increase any or all of the following: the yield of livestock fodder as a provisioning service; regulating services for long-term ecological resilience; or other services garnered via nonpastoral land uses such as wildlife ecotourism. Because people's perceptions of ecosystem services are not static, the adoption of new livelihood strategies may shift the benefits they perceive (Berkes et al. 2000, Agrawal 2007, Díaz et al. 2011). For example, if a pastoralist community begins to pursue wildlife-based ecotourism, people's priorities among rangeland ecosystem services may shift away from provision of livestock fodder toward maintenance of attractive habitat for wildlife. Improved management can potentially increase the yield of more than one service, but it can also bring new trade-offs to the fore, particularly if a desired service is extractive, like grazing, or excludes other land uses (Rodríguez et al. 2006, Bennett et al. 2009, Hicks et al. 2013, Cavender-Bares et al. 2014).

Third, even when potentially effective resource management institutions are identified, community-wide levels of social capital can influence the likelihood of successful collective action for CPR management (Pretty 2003, Ballet et al. 2007, Sanginga et al. 2007, Lesorogol 2008). In most pastoralist societies, strong customary norms of reciprocity are an important form of bonding social capital, providing commitment among community members and a safety net for households when they suffer herd losses or hardships (Galvin 2008, Goldman and Riosmena 2013). However, the ongoing transitions toward greater social fragmentation and food insecurity may in fact erode traditional forms of social capital (Jones 2005, Galvin 2008). Thus, we argue that the implementation and success of new resource conservation strategies may vary with the degree of social capital to engender collective action, as well as local people's perceptions of resources and ecosystem services, as described previously.

In pastoralist communities in transition, we expect that these 3 classes of issues will influence the evolution and effectiveness of emerging NRM strategies. We present a comparison of 5 Laikipia Maasai communities in north-central Kenya, which share similar cultural backgrounds, customary land-use practices, and climate conditions. However, they have had divergent experiences in recent decades in their partnerships with benefactor organizations, experience with development initiatives, and their individual histories of internal governance issues. In the past 12 years, 4 of the 5 communities established some form of grazingrestricted conservation area with the support of an external partner organization, and only 1 has succeeded in maintaining that area through endogenously generated collective action (Kaye-Zwiebel 2011). We seek to investigate whether these communities today show variation in their perceptions of ecosystem services and levels of social capital, either or both of which may influence their decision making and success in adopting new conservation measures.

Based on household demographic surveys and questionnairebased interviews conducted in each community, we assessed individual perceptions of scarcity of two key ecological resources for pastoralists, forage availability and livestock abundance. Then we assessed individual perceptions of the importance of multiple ecosystem services, including benefits to livestock, benefits to wildlife, and economic benefits, garnered from grazing-restricted conservation areas in four of the five communities. Finally, we evaluated three indicators of social capital in each of the communities: household-to-household reciprocity, frequency of sanctioning, and norms of fairness. For additional context 
regarding future land-use preferences, we also include an analysis of attitudes in each community toward land privatization as a management option. Our aim is to consider how these factors vary among the five pastoralist communities in transition and to explore how they may relate to the implementation and effectiveness of emerging NRM institutions.

\section{STUDY SYSTEM}

We conducted the study in 5 Laikipia Maasai communities on the northern boundary of Laikipia County in north-central Kenya (Fig. 1), herein referred to as $\mathrm{C} 1$ through $\mathrm{C} 5$. The land is semiarid savanna and Acacia bushland, receiving $<500 \mathrm{~mm}$ average rainfall per year, concentrated in 2 rainy seasons annually, with high interannual variability (coefficient of variation $>40 \%$; T. E. Franz, unpublished data). Rainfall variability is increasing (Franz 2010, Franz et al. 2010), and drought cycles appear to be growing shorter (Kaitho et al. 2006, Thornton et al. 2006).

Fig. 1. Location of study communities in Laikipia County, Kenya.

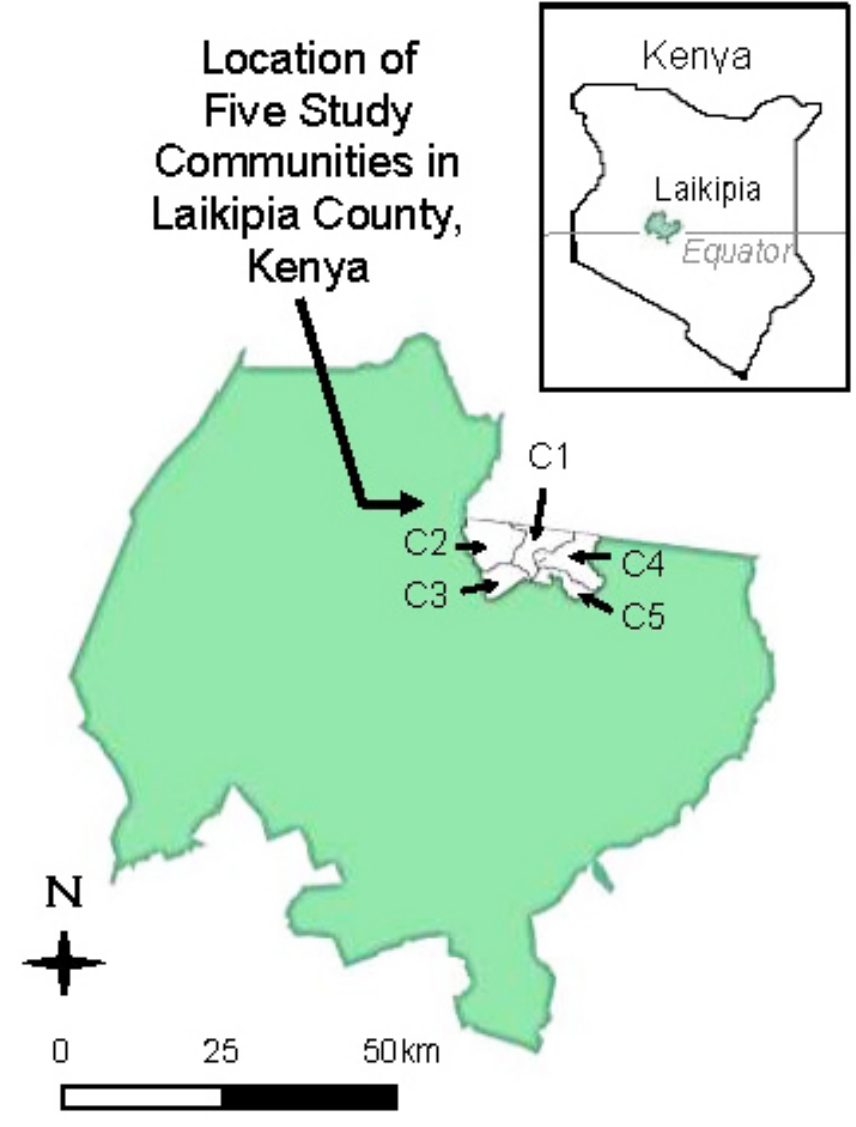

Residents of these communities are primarily subsistence pastoralists who have traditionally kept mixed herds of cattle, goats, and sheep. Historically, these communities utilized a customary governance system to manage extensive grazing, in which land-use decisions were made by bodies of elders. In the early 1970s, the Government of Kenya instated a new land tenure and statutory governance system in this region and other pastoralist areas, creating what are known as Group Ranches. Each Group Ranch is owned communally by the traditional residents of the delineated area. Each of the five communities studied is a separate Group Ranch. Thus, all communities share a common land tenure system and statutory governance structure, which consists of an annually elected governing committee. However, the Group Ranch governance system was not adopted in practice until the late 1990s, when communities sought and obtained the title deeds to their Group Ranches. Today, all five communities adhere to the legal requirements of maintaining an elected committee, yet in practice, each community uses a blend of customary and statutory governance and land management institutions.

In response to frequent droughts and limited mobility, herd sizes have declined (Herren 1991). Today, formal education is becoming more prevalent, and some residents are adopting other economic activities and seeking employment outside the community. All of the communities have also created new land-use practices, delineating mixed grazing/residential areas and areas for grazing only. Between 2001 and 2004, all of the communities except C5 also established grazing-restricted conservation areas within their boundaries. Each conservation area was created in collaboration with one or two partner organizations, i.e., tourism companies, international conservation nongovernmental organizations, and neighboring privately owned ranches. $\mathrm{C} 1$ established a grassland rehabilitation project and a grazing set-aside area, but no tourism facilities. The other three communities' conservation areas were established around ecotourism lodges operated by partner organizations. The purpose of those latter areas was to enhance wildlife and tourism and also to serve as emergency grazing. In all cases, conservation areas were established though a participatory process. Communities are responsible for compliance with management plans. From establishment until the time we conducted the study, $\mathrm{C} 1$ was the only community to consistently adhere to its management plan (Kaye-Zwiebel 2011).

\section{METHODS}

Prior to conducting research, we sought and obtained the permission of each community. See Appendix 1 for details on community engagement, enumerator training, and additional details of census, survey, and economic game methodologies, as well as details of statistical analyses.

\section{Household census and surveys}

We conducted a full census of all households in all 5 communities between December 2008 and February 2009. We used residential compounds as the household unit. Enumerators systematically traveled through residential areas, approaching each residential compound, explaining the nature of the census, and asking if the residents were willing to participate. Every household was cooperative. To complete the census, an adult household member was asked to report the number of men, women, warriors, and children in each household, as well as the household's total holdings of each livestock species. Livestock numbers were converted to Tropical Livestock Units (TLU), and household numbers to Active Adult Male Equivalents (AAME) as described in Appendix 1. The census identified just over 550 households with 6900 individuals living in them. 
In June and July 2009, enumerators conducted opinion surveys with a subset of 28 to 51 households in each community, selected via stratified random sampling within 3 livestock wealth categories, which were determined based on the initial full census (Kaye-Zwiebel 2011). One adult per household was usually interviewed, and the respondent's age recorded, except for attitudes regarding subdivision, for which 2 adults per household were interviewed (see Appendix 1). The surveys posed questions with constrained answer choices. Two questions aimed to gauge perceptions about scarcity of ecological resources, namely whether communal forage was adequate for the livestock in the community and whether their household herd size was adequate for their livelihood needs. Respondents were asked which of 5 potential ecological and economic benefits they felt they gained from conservation areas. Surveys also asked questions to ascertain whether households were engaged in livestock lending, how often they were recipients of interhousehold food sharing, and whether anyone in their household had been sanctioned with any fines in the past 3 years. When possible, 2 individuals from each household, male and female, were asked whether they thought that future land subdivision and privatization would be a good, bad, or mixed idea. The survey texts in English are provided in Appendix 1, along with additional details regarding methodology.

\section{Experimental games}

In July 2009, we staged multiple rounds of an experimental economic game, the Ultimatum Game, which assesses norms of fairness in a population (Henrich et al. 2005). In this 2-person game, one player assumes the role of the "proposer," and the other is the "respondent." The game begins by explaining the following scenario to all players: the proposer will receive 20 goats and must offer a proportion of that stake to another community member, the paired responder. If the responder agrees to the proportion offered, each player is paid in goats according to the proposer's offer. If the responder rejects the offer, neither player receives a payout. It is thus incumbent on the proposer to make an acceptable offer, according to norms of fairness, to avoid rejection. It is assumed that the proposer is motivated to make an offer that he believes the paired responder will deem fair and accept, so that the proposer will receive a payment. Thus, the proposer's offer is the response variable of interest, treated as an indication of a norm of fairness.

Volunteers from communities were solicited on 2 days in each community. Players were randomly assigned to be proposers or responders but did not know the identity of their paired partner. When the game was explained, players understood that they would receive cash payouts, at the rate of 10 Kenyan shillings (KSh) per goat in the scenario, according to their offers and whether the offer was accepted. Thus, each team would either share or lose $200 \mathrm{KSh}$ (US $\$ 2.50$, or $\sim 1$ day's basic labor wage). As games were played, proposers privately reported their offer to the researchers, then respondents were privately told what their anonymous partner offered, and they responded to accept or reject. Finally, all participants were paid according to their offers and acceptances or were not compensated if a responder rejected (see Appendix 1 for details).

\section{Analyses}

We used three sources of data to support qualitative observations of similar forage production across communities. First, the
Global Livestock Early Warning System outputs showed similar average standing forage of 980 to $1055 \mathrm{~kg} / \mathrm{ha}$ for the study communities (CNRIT 2011). Range condition assessment in 3 of the communities $(\mathrm{C} 1, \mathrm{C} 2$, and $\mathrm{C} 4)$ showed similar conditions in all land-use zones in each community (Oguge 2005). Finally, a study in 3 communities $(\mathrm{C} 1, \mathrm{C} 2$, and $\mathrm{C} 3$ ) showed comparable grass densities along livestock-grazing routes (E. G. King and D. I. Rubenstein, unpublished data). We thus inferred that the communities did not have substantially different levels of forage production (see Appendix 1 for details).

We used chi-square contingency analyses for community differences in perceptions of forage livestock herd sufficiency, responses regarding specified potential benefits from conservation areas, livestock lending, fines, and attitudes toward subdividing. We used logistic regression to test whether perceptions were predicted by household livestock wealth (TLU), per capita livestock wealth (TLU/AAME), or the age of the respondent. We used ANOVA to test for community variation in the food sharing. Appendix 1 provides a table and further details of all analyses. Statistical analyses were performed using JMP Pro 10.0.0 software (SAS Institute 2012).

\section{RESULTS}

\section{Perceptions of ecosystem services: forage scarcity and livestock resources}

Rates of grazing land availability in communities ranged from 2.3 to $3.9 \mathrm{ha}$ /TLU (Table 1). This was considerably denser than preferred rates of 10-12 ha/TLU reported by privately owned commercial livestock ranches in the area (Kaye-Zwiebel 2011). When residents were asked if their community's land was sufficient to support all the livestock in the community, the proportion of positive responses varied widely among communities (Fig. 2a; $\chi^{2}[4, n=178]=54.8, p<0.0001$ ). Residents in $\mathrm{C} 4$ had the most negative perception of grazing land sufficiency, with only $10 \%$ of individuals perceiving resources as adequate. In the other communities, grazing resources were more commonly perceived as sufficient, ranging from $41 \%$ to $87 \%$ positive responses. Despite these quite different response rates among communities, and a 2-fold difference in grazing availability between the most and least densely stocked communities, we saw no perceptible trend or correlation between the proportions of positive responses and the grazing availability rates (ha/TLU) calculated for the communities $\left(n=5, \mathrm{r}^{2}\right.$ adjusted $\left.=0.002, p=0.39\right)$. Although we cannot place great confidence in this regression with only 5 data points, perceptions do not seem to vary in accordance with gross differences in stocking rates. Also, individual perceptions of forage sufficiency did not vary according to respondents' household total livestock, per capita livestock wealth (TLU/AAME), or age (household TLU $\chi^{2}[1, n=177]=$ $0.09, p=0.76$; TLU/AAME $\chi^{2}[1, n=177]<0.001, p=0.99$; age $\left.\chi^{2}[1, n=177]=0.49, p=0.48\right)$.

When community members were asked whether their household livestock herds were sufficient to meet their livelihood needs, the majority of respondents $(78 \%)$ perceived that their household herd size was inadequate. The response rate varied significantly among communities $\left(\chi^{2}[4, n=178]=17.6, p=0.0015\right)$, ranging from $60 \%$ to $91 \%$ of respondents giving a negative response (Fig. $2 \mathrm{~b}$ ). Individual perceptions of livestock resource sufficiency were 
Table 1. Characteristics of community demographics, conservation areas, and external partner organizations.

\begin{tabular}{|c|c|c|c|c|c|}
\hline Community & $\mathrm{C} 1$ & $\mathrm{C} 2$ & $\mathrm{C} 3$ & $\mathrm{C} 4$ & $\mathrm{C} 5$ \\
\hline Group Ranch Name & Tiemamut & Koija & Il Motiok & Kijabe & Musul \\
\hline \multicolumn{6}{|l|}{ Human and livestock demographics: } \\
\hline Population (persons) & 1188 & 2267 & 999 & 1604 & 1155 \\
\hline Households (HH) & 100 & 197 & 71 & 119 & 77 \\
\hline Average $\mathrm{HH}$ size (persons/HH) & 10.5 & 11.4 & 12.5 & 14.1 & 14.6 \\
\hline Area (ha) & 5420 & 7605 & 3651 & 6480 & 2749 \\
\hline Total Livestock Units $\left(\mathrm{TLU}^{\dagger}\right)$ & 1836 & 3745 & 1056 & 2700 & 1052 \\
\hline Forage area availability (ha/TLU) & 2.95 & 2.03 & 3.46 & 2.40 & 2.61 \\
\hline Average TLU/AAME & 1.82 & 1.91 & 1.43 & 1.83 & 1.13 \\
\hline Proportion of $\mathrm{HH}$ with $<2.0$ TLU/AAME ${ }^{\S}$ & 0.73 & 0.65 & 0.81 & 0.67 & 0.83 \\
\hline Conservation area size (ha) & 50 & 200 & 400 & 2000 & none \\
\hline \multicolumn{6}{|l|}{ Rationale \& expected benefits:! } \\
\hline Ecotourism: development \& jobs & $x$ & $\sqrt{ }$ & $\sqrt{ }$ & $\sqrt{ }$ & $\mathrm{n} / \mathrm{a}$ \\
\hline Fees per lodge guest & $\times$ & $\sqrt{ }$ & $\sqrt{ }$ & $\sqrt{ }$ & $\mathrm{n} / \mathrm{a}$ \\
\hline Fees for land lease & $x$ & $x$ & $x$ & $\sqrt{ }$ & $\mathrm{n} / \mathrm{a}$ \\
\hline In-kind services \& infrastructure & $x$ & $x$ & $x$ & $\sqrt{ }$ & $\mathrm{n} / \mathrm{a}$ \\
\hline Land rehabilitation & $\sqrt{ }$ & $\sqrt{ }$ & $\sqrt{ }$ & $x$ & $\mathrm{n} / \mathrm{a}$ \\
\hline Wildlife conservation & $x$ & $\sqrt{ }$ & $\sqrt{ }$ & $\sqrt{ }$ & $\mathrm{n} / \mathrm{a}$ \\
\hline Reserve grazing & $\sqrt{ }$ & $\sqrt{ }$ & $\sqrt{ }$ & $x$ & $\mathrm{n} / \mathrm{a}$ \\
\hline Beekeeping & $\sqrt{ }$ & $x$ & $x$ & $x$ & $\mathrm{n} / \mathrm{a}$ \\
\hline Past lapses in management compliance & $x$ & $\sqrt{ }$ & $\sqrt{ }$ & $\sqrt{ }$ & $\mathrm{n} / \mathrm{a}$ \\
\hline Grazing access rules & $\begin{array}{l}\text { Mgmt can } \\
\text { allow, but } \\
\text { never has. }\end{array}$ & $\begin{array}{l}\text { Partially } \\
\text { opened in } \\
\text { droughts. }\end{array}$ & $\begin{array}{l}\text { Partially } \\
\text { opened in } \\
\text { droughts. }\end{array}$ & $\begin{array}{l}\text { Mgmt never } \\
\text { allows. }\end{array}$ & $\mathrm{n} / \mathrm{a}$ \\
\hline Major external partner organization & Int'1 NGO & Private Ranch & Private Ranch & $\begin{array}{l}\text { Lodge } \\
\text { Operator }\end{array}$ & Private Ranch \\
\hline Partner organization location & City & Neighbor & Neighbor & On-site & Neighbor \\
\hline Partner operates tourism facility & $\mathrm{n} / \mathrm{a}$ & Yes & No & Yes & $\mathrm{n} / \mathrm{a}$ \\
\hline $\begin{array}{l}\text { Total monetary and in-kind benefits received from } \\
\text { partner (US\$ equivalent / person / year) }\end{array}$ & 33 & 48 & 34 & 155 & 9 \\
\hline
\end{tabular}

${ }^{\dagger}$ See Appendix 1 for conversion of livestock breeds to (TLU)

$\$$ See Appendix 1 for conversion of age and gender groups to Active Adult Male Equivalents (AAME)

$\S$ In pastoralist societies, herd sizes ranging from 2.0 to 5.0 TLU/AAME are variously used as benchmarks of sufficiency for subsistence. We have encountered no scholarly reports that consider herd sizes of less than 2.0 TLU/AAME to be sufficient to sustain a pastoralist livelihood. Thus households below this threshold are considered to be too livestock-poor to subsist as pastoralists.

Information compiled from multiple sources (Oguge 2005, Kenya Land Conservation Trust 2009, Kaye-Zwiebel 2011, Muthiani et al. 2011; E. Kaye-Zwiebel and E. King, personal observation).

not correlated with the respondents' household total or per capita livestock wealth $\left(\right.$ TLU $\chi^{2}[1, n=178]=2.86, p=0.09$; TLU/AAME $\left.\chi^{2}[1, n=178]=0.60, p=0.44\right)$ or age $\left(\chi^{2}[1, n=178]=3.38, p=\right.$ $0.07)$.

When we compared individuals' perceptions of livestock sufficiency to their perceptions of forage scarcity, we found that those who reported sufficient herd size were less likely to perceive that grazing resources were also sufficient $\left(\chi^{2}[1, n=178]=3.86\right.$, $p=0.050$; Fig. 2c). Among the respondents who perceived one or the other resources as limiting, the majority $(75 \%)$ thought herd size was the insufficient resource. Thirty-five percent of respondents perceived both their household's livestock and grazing resources to be insufficient, and only $8 \%$ reported that both were adequate.

\section{Perceptions of ecosystem services: values associated with conservation areas}

In the 4 communities that had conservation areas, respondents were asked whether their conservation area provided any of 5 potential benefits: 3 different ecosystem services and 2 economic benefits. There was significant community-to-community variation in all the perceived benefits for land health, livestock, and wildlife $\left(\chi^{2}[3, n=142]>20, p<0.0001\right.$ for all 3 variables; Fig. $3 \mathrm{a}-\mathrm{c})$. Most communities showed nearly unanimous recognition of these ecological benefits. The exception was $\mathrm{C} 4$, in which a much smaller proportion of members acknowledged those ecosystem services, especially services that benefit pastoralist livelihoods, i.e., land health and herd heath. There were also differences among communities in perceived economic benefits 
Fig. 2. Community member responses regarding sufficiency of (a) grazing resources in the community and (b) household livestock resources. Numbers of respondents were 25, 49, 30, 40, and 34 for communities C1 through C5. Panel (c) presents the $2 \times 2$ contingency analysis of grazing sufficiency responses by livestock sufficiency responses, for all communities combined. The columns separate respondents according to their perceptions of livestock sufficiency, and the dark/light division within columns shows their perceptions of grazing resource sufficiency household. In each block, sample size and percentage of column total are given. All contingency analyses (panels a, b, c) were significant at the $\alpha=0.05$ level; see Results for details.
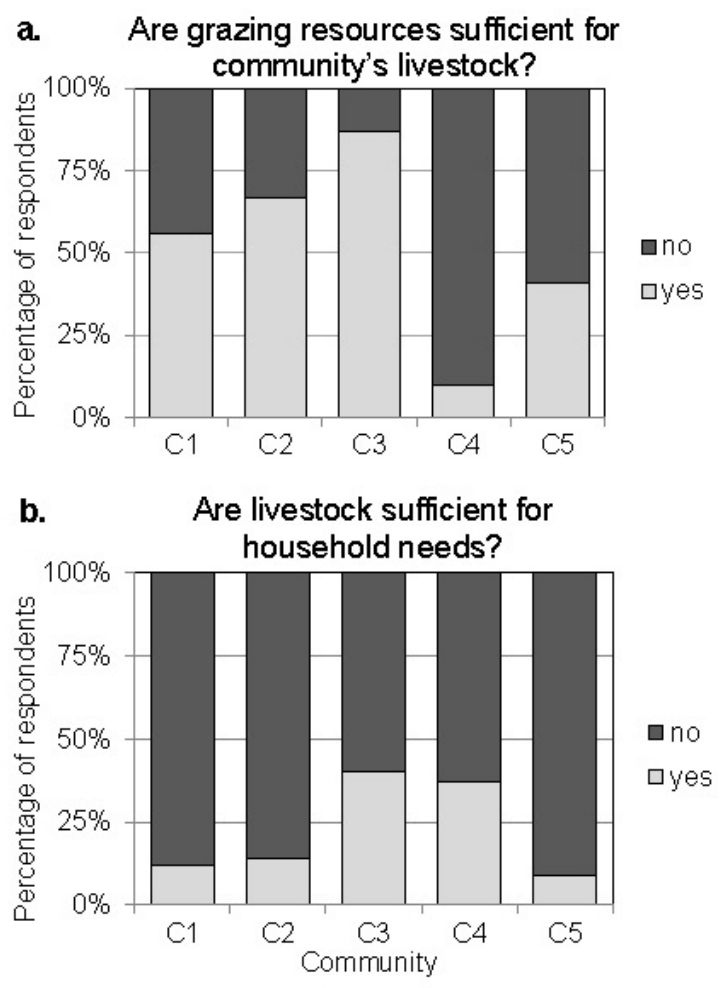

c. Views on grazing sufficiency, depending on household livestock sufficiency

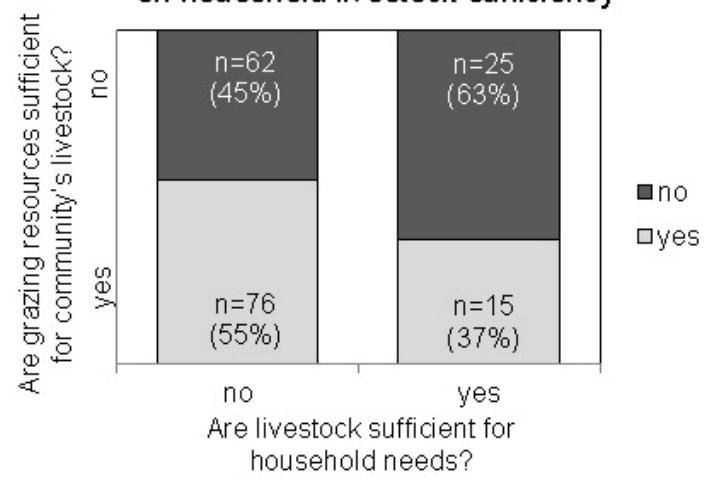

from conservation areas, which included payments for maintaining the conservation area, and provision of employment $\left(\chi^{2}[3, n=142]>30, p<0.0001\right.$ for both; Fig. 3d, e). Overall, responses in community $\mathrm{C} 4$ diverged most strongly from the other communities. This was also the community with distinctly lower perceptions of grazing resource sufficiency than other communities.

A comparison between community perceptions of livestock benefits and employment benefits reveals an interesting pattern. Communities that more frequently perceived that conservation areas offered benefits to livestock health tended to perceive fewer benefits from employment (Fig. 3b vs. Fig. 3e). We examined whether this inverse relationship in community-level responses was also manifest at the level of individuals' responses. Indeed, a contingency analysis of individuals' responses to these 2 questions, pooling residents from all communities, showed a significant, negative association between individuals' responses to these 2 questions $\left(\chi^{2}[1, n=142]=13.81, p=0.0002\right)$. People who perceived an employment benefit were less likely to perceive a benefit to livestock than would be expected if their answers to these questions were independent of one another (Fig. 3f). Of the people who perceived that there were employment benefits from conservation areas, $56 \%$ also perceived benefits to livestock; whereas among the people who perceived no employment benefits, $89 \%$ perceived livestock benefits.

\section{Assessments of social capital}

Measures of reciprocity, assessed via frequency of food sharing and frequency of long-term livestock lending, varied significantly among communities (sharing $F_{4142}=3.05, p=0.019$; lending $\chi^{2}$ $[4, n=164]=22.9, p<0.0001)$. Respondents from C1 and C3 reported the greatest frequency of receiving food, an average of 5 days per month (Fig. 4a). However, across all communities, sharing of food was common; $81 \%$ of households reported eating food that was given to them by others in the past month. Residents of $\mathrm{C} 1$ and $\mathrm{C} 2$ reported the highest rates of long-term livestock lending to other households, with $37 \%$ and $52 \%$ of households currently lending livestock to another household, respectively (Fig. 4b). Overall, the traditional practice of lending livestock to other households was not very prevalent in the communities we studied.

We found that communities differed significantly in their rates of sanctioning to enforce rules, assessed as the proportion of households that reported having been fined in the past 3 years $\left(\chi^{2}\right.$ $[4, \mathrm{n}=155]=16.2, p=0.003$; Fig. $4 \mathrm{c})$. Although sanction-meriting offenses include livestock theft, adultery, and grazing in conservation areas, the most common reasons for fines were petty theft and fighting (Kaye-Zwiebel 2011). As the frequency of these infractions was not expected to vary among communities (KayeZwiebel 2011), we interpreted fining rates as an indicator of the community's propensity to issue fines, rather than an indicator of frequency of transgressions. Again, $\mathrm{C} 1$ and $\mathrm{C} 3$ reported the highest rates of sanctioning, with $33 \%$ and $40 \%$ of interviewed households reporting fines, respectively. Communities were ranked according to each variable, then the ranks were averaged; $\mathrm{C} 1$ had the highest average ranking for these forms of social capital, followed by $\mathrm{C} 2$ and C3 (equally ranked), then $\mathrm{C} 4$, and then $\mathrm{C} 5$. 
Fig. 3. Perceived benefits from conservation areas and economic inputs from conservation partner organizations. (a-e) Community member responses to the question, "Do you think your conservation area is good because ... ?" The panel titles complete the sentence. (f) Contingency analysis of livestock health perceptions by perceptions of employment benefits. The columns separate respondents according to their perceptions of employment benefits from their conservation area, and the dark/light division within columns shows their perceptions of conservation area benefits for livestock health. In each block, sample size and percentage of column total are given. In all panels, analyses revealed significant variation at the $\alpha=0.05$ level.
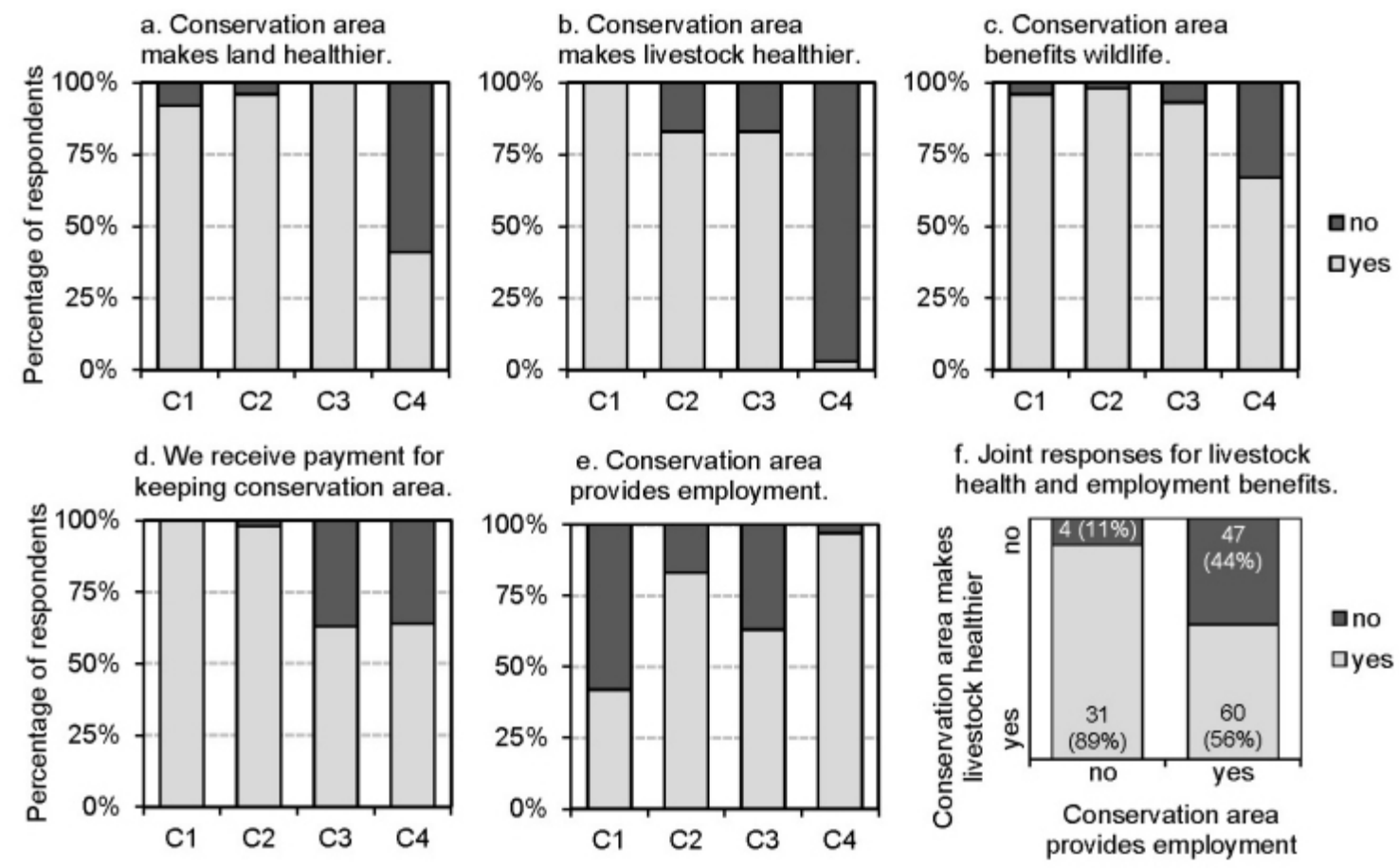

We analyzed the proposers' offers from the Ultimatum Game to assess norms of fairness. In this economic game, the proportion of the stake, in this case contextualized as 20 goats, that is offered to the anonymous partner is expected to represent the proposer's normative idea of a fair offer. In all communities except $\mathrm{C} 1$, the proposer's offers were clearly bimodally distributed, $\sim 25 \%$ and $50 \%$ of the stake. $\mathrm{C} 1$, on the other hand, showed a unimodal distribution of offers, with $25 \%$ as the mode (Fig. 5).

\section{Perceptions of resource management institutions}

When respondents were asked whether subdividing and privatizing their land in the future would be a good, mixed, or bad idea, communities showed varying responses $\left(\chi^{2}[8, n=247]\right.$ $=65.7, p<0.0001$; Fig. 6 ). Only in $\mathrm{C} 1$, the community exhibiting successful collective action to manage its conservation area, did the majority of respondents perceive privatization as good or acceptable.

\section{DISCUSSION}

\section{Perceptions of resource scarcity}

Communities varied in their perceptions of forage scarcity, but livestock abundance was generally viewed as a greater limitation than forage abundance. This trend is not surprising in the context of nonequilibrium dynamics in dryland pastoralist systems, where abiotic conditions of dry seasons and periodic droughts tend to limit livestock numbers more strongly than forage availability. Under these conditions, the strategy of maximizing herd size has been shown to represent a good adaptive fit because herds are decimated by droughts frequently enough that they do not cause chronic overgrazing and maximizing reproduction allows recovery from those events (Ellis and Swift 1988, Behnke and Scoones 1993). Herren (1991) and Letai and Lind (2013) have pointed out that restricted mobility has also heavily impacted herd sizes in the region. We found that $90 \%$ of households had fewer livestock than is considered the bare minimum for pastoralist sustenance (Table 1). A traditional tendency toward herd maximization, coupled with the reality of reduced livestock, offers a reasonable explanation for why perceptions of livestock scarcity were more salient than forage scarcity.

Our hypothesis was that without recognition of forage scarcity, there would be little impetus to develop or maintain a resource conservation strategy. Communities did not express a widely held or urgent perception of forage scarcity that would be expected to motivate and foster collective action to address the problem through new management strategies (Quinn et al. 2003, Santos and Pacheco 2011). The perceived, and actual, scarcity of livestock, on the other hand, may provide impetus for individuals and communities to seek supplementary or alternative livelihood means. Conservation areas have the potential to do this, depending on their design. 
Fig. 4. Indicators of traditional forms of social capital varied significantly among study communities. (a) Interhousehold food sharing: respondents reported how many days in the past month they consumed food borrowed from another household (means \pm SE). (b) Long-term livestock lending: households reported whether they were currently engaged in the customary practice of lending livestock to other households for several months or years. (c) Sanctioning for rule violations: households reported whether they had been assessed with a fine for rule violation within the past 3 years (until April 2009), which was interpreted as an indicator of a community's propensity to sanction. Each indicator varied significantly among communities; numbers on bars indicate rank order of communities for each indicator.

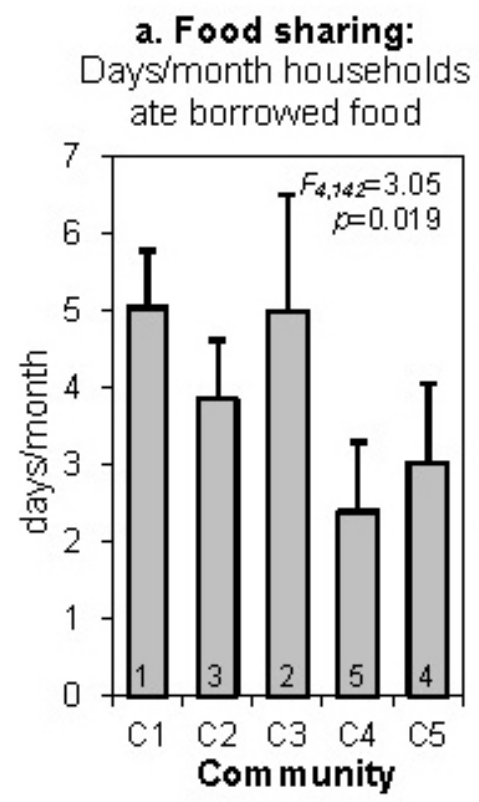

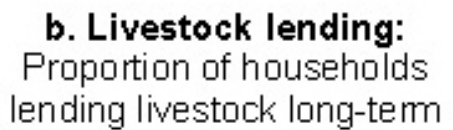

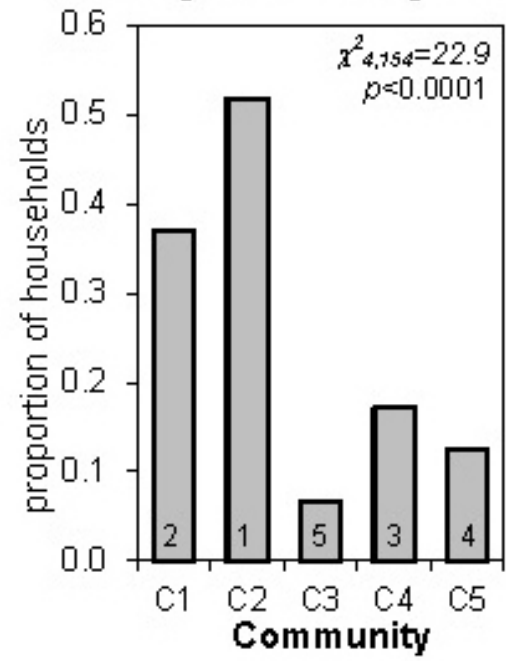

c. Sanctioning:

Proportion of households that paid fines in 3 yrs

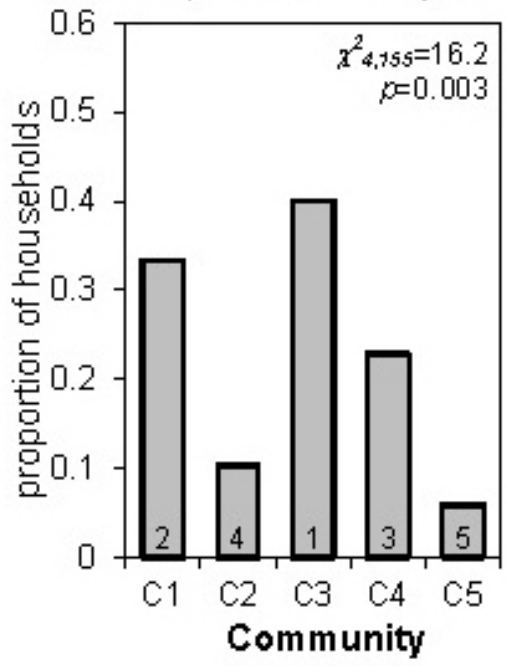

\section{Ecological and economic benefits from conservation areas} Conservation areas, which were established in cooperation with external organizations in four of the five communities, are an innovative land-use strategy in this region. The rationales for each conservation area were developed through independent processes, resulting in different objectives, terms, and conditions for each community. Because of these design differences, each conservation area offers a different suite of potential ecological and economic benefits (Table 1). The goals and rules, in combination with people's subsequent experiences, may shape community perceptions of ecosystem services and benefits garnered from conservation.

In three communities ( $\mathrm{C} 2, \mathrm{C} 3$, and $\mathrm{C} 4)$, partner organizations built an ecotourism facility within the conservation area, bringing opportunities for employment. In all three of these communities, residents acknowledged employment as a benefit from the conservation area, with employment benefits being most widely recognized in $\mathrm{C} 4$. Three of the communities maintained the authority to utilize the conservation area as reserve grazing, whereas in $\mathrm{C} 4$ the partner organization does not allow grazing under any circumstances. In parallel to differing grazing access rules, we found that very few residents of $\mathrm{C} 4$ reported that the conservation area provided benefits to their livestock, whereas this perception was dominant in the other three communities.

An examination of community-to-community divergences revealed a negative association between perceived benefits for livestock and employment benefits (Fig. 3f). We found that if a person perceived that a conservation area provided employment, that person was less likely to perceive benefits to livestock as well. The activities and management rules in the conservation areas are likely the source of this perceived trade-off between ecological services and economic benefits. The two communities (C2 and C3) that had ecotourism facilities and also allowed some grazing in the conservation area during droughts showed the most balanced perspectives of both types of benefits. Community $\mathrm{C} 4$ showed the clearest divergence from the other communities, with residents perceiving mostly economic benefits rather than ecosystem services. This is understandable, given that the partner organization provides substantial economic inputs while prohibiting pastoral use of the conservation area (Table 1).

These findings are compatible with our hypothesis that communities' experiences with conservation areas shape residents' perceptions about the ecological and economic values associated with their land. We believe this is important because the evolving values may shape future decision making. Under this hypothesis, if a conservation area like the one at $\mathrm{C} 4$ succeeds in providing economic benefits, the community may continue favoring land uses that yield mainly economic rewards and few benefits to customary pastoralism. This could pose challenges if different stakeholders in a community develop divergent preferences, for instance if residents who are reliant on livestock feel that they are losing resources critical to their livelihoods. 
Fig. 5. Offers given by Player 1, the proposer, in the Ultimatum Game. Histograms show frequency of offers of varying amounts; the distribution of offers is used as an indicator of norms of fairness in a community. Offers by $\mathrm{C} 1$ players exhibit a unimodal distribution, with the mode offer being $25 \%$ of the stake; whereas offers from other communities were bimodally distributed, around modes at $25 \%$ and $50 \%$ of the stake. Sample size in each community indicated on graph.
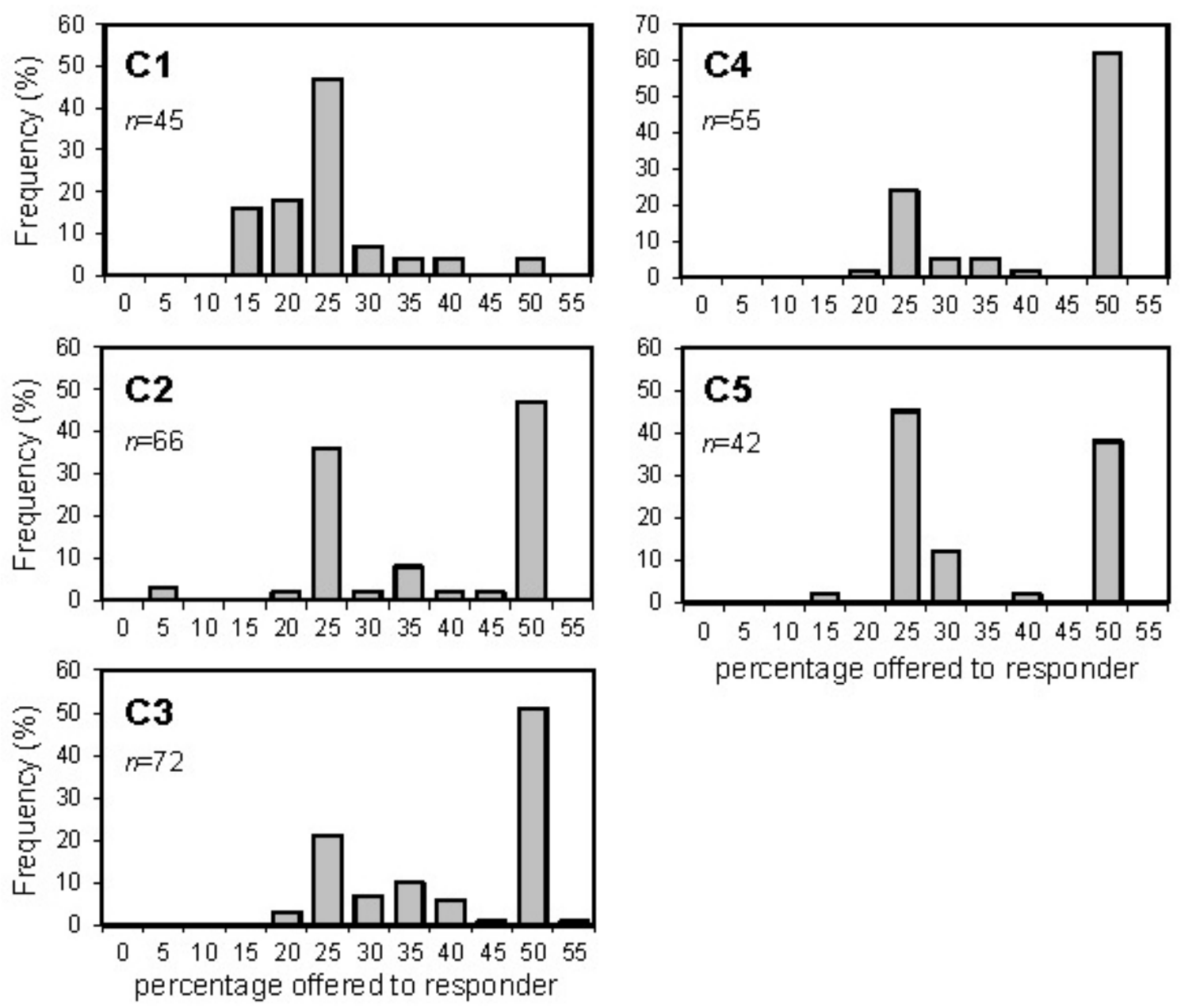

Numerous accounts from development projects have shown that such trade-offs can form an underlying source of tension in decision making and management (Tallis et al. 2008, Bullock et al. 2011, McShane et al. 2011). Cavender-Bares et al. (2014) have proposed a trade-off analysis framework as a way to characterize divergent preferences for different services and benefits yielded from a common resource. The framework is intended to facilitate the development of mutual understanding of different groups' perceptions and preferences and thereby move them toward more equitable and sustainable outcomes. Partnerships that bring alternative livelihoods can enhance community resilience when they robustly integrate and respond to community aspirations and forms of knowledge (Reid et al. 2009). On the other hand, they can bring about additional trials and hardships if they have not fully reconciled both sides' values and ensuing trade-off preferences for the project (e.g., Rutten 2002). Knowledge of preexisting divergences in values is particularly relevant for conservation or development initiatives that span multiple communities. Such divergences may explain why a strategy for livelihood improvements succeeds in one community but is received apathetically or even rejected in another.

\section{Social capital, cooperation, and CPR management}

The literature on traditional pastoralism has documented the importance of social capital in CPR management and also in providing social cohesion and "safety nets" that help buffer people from risks imposed by harsh and variable environmental conditions (Fratkin 1986, Niamir-Fuller 1998, Potanski 1999, McPeak 2005). Because the communities we studied are undergoing social and political reorganization, we sought to evaluate whether these customary adaptive phenomena are still strongly manifest and whether levels of social capital show community-to-community divergence. Our objective was to assess the relative strengths of multiple forms of social capital that are adaptive for maintaining resilience, cohesion, and 
collective action for CPR management in traditional pastoralism. The three manifestations of social capital we assessed were reciprocity, sanctioning, and norms of fairness.

Reciprocity is a key adaptation in pastoralism, which scholars have interpreted as a culturally imbued way to ensure recovery assistance when an individual suffers losses (McPeak 2006). In addition, reciprocal exchanges build trust and interdependency, which act as social capital to facilitate cooperation and collective action (Pretty 2003). In Maasai culture, reciprocity is manifest in numerous ways; two of the most salient are food sharing between households and long-term lending of livestock (Potanski 1999). In the communities we studied, food sharing was fairly common overall but was most frequent in $\mathrm{C} 1$ and $\mathrm{C} 3$. Long-term livestock lending, on the other hand, was not as common and showed stronger differences between communities. In $\mathrm{C} 1$ and $\mathrm{C} 2,37 \%$ and $52 \%$ of households were lending animals, respectively; whereas in the other communities, only $7-17 \%$ of households were lending stock. Further information on animals lent, owner herd composition, and ethnographic elaboration on the reasons for loans would be required to determine whether these lower rates of lending represent a culturally mediated decrease in this traditional form of reciprocity or whether reciprocity is being constrained by animal availability or other factors.

In pastoralist systems, complex polycentric governance structures have customarily negotiated seasonal grazing, imposed grazing restrictions, regulated large-scale livestock movements, and meted out punishment for crimes like theft and violence (Thébaud and Batterbury 2001). Imposing sanctions is an important way by which a community demonstrates its capacity for self-governance and CPR management (Ostrom 1990a, Dietz et al. 2003). We saw variation in communities' propensity to impose fines, which raises concerns that all communities may not have equal capacity to use traditional sanctioning to effectively govern a new resource management system like a conservation area.

Finally, the Ultimatum Game seeks to evaluate norms of fairness via the proposing player's offers. The percentage of the stake that a player offers is expected to reflect a culturally held norm of a "fair" division. Sharing a norm of fairness is itself a form of social capital because if people share a common notion of a fair offer, they know what to expect of one another. This allows greater trust, thereby reducing transaction costs in cooperative endeavors and facilitating collective action, as explained in the context of Samburu communities in Kenya, which are closely related to Laikipia Maasai, by Lesorogol (2008). When offers across a community are all very similar, it indicates that there is a widely shared norm. We found that 4 communities showed a distinctly bimodal distribution of offers in the Ultimatum Game. This indicates that within those communities, there was no single norm of fairness regarding sharing a stake: some people thought it was fair to give a partner $25 \%$, whereas others deemed it fair to give half. In contrast, $\mathrm{C} 1$ had a unimodal distribution of offers, centered $\sim 25 \%$. This suggests a stronger norm of fairness because there was community-wide consensus of what is considered fair. Furthermore, the amount of a $25 \%$ offer has been associated with older, more traditional norms of fairness in sharing (Lesorogol 2008).

It is interesting to note that $\mathrm{C} 1$, the community with the highest levels of traditional social capital in terms of livestock lending, food sharing, sanctioning, and strong norms of fairness, is also the only community that has not undergone lapses in governance of their conservation area (noted in Table 1). With so few communities as samples, and so many additional factors that can affect CPR management, any claim of a causal relation would be speculative at this point. In fact, our final analysis raises a cautionary flag regarding the assumption that strong traditional social capital and current management compliance will lead to more robust CPR management in the future. When asked to consider the possibility of moving away from communally held land in the future, $\mathrm{Cl}$ was the only community in which the majority of residents tolerated or favored the idea of subdividing and privatizing the land (Fig. 6). The community that appears to have the strongest social assets for maintaining a resilient communally based pastoral livelihood is, apparently and ironically, the most willing to give it up.

Fig. 6. Community members' perceptions about land subdivision and privatization. Respondents were asked whether they believed that future subdivision and privatization of land would be a good idea, a mixed or tolerable idea, or a bad idea. Perceptions varied significantly among communities $\left(\chi^{2}[28, n=\right.$ 247] $=65.7 ; \mathrm{p}<0.0001)$.

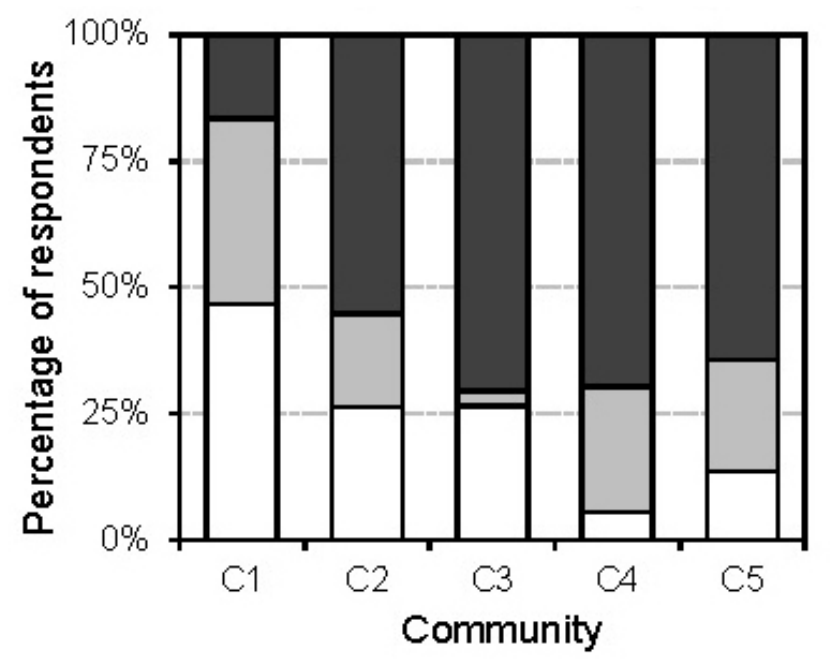

abadidea $\square$ mixed/tolerable $\square$ goodidea

\section{CONCLUSIONS}

The communities studied are undergoing a suite of transformations. All communities share a background as subsistence pastoralists, using rangelands extensively under customary governance. However, each community is experiencing novel ecological dynamics, livelihood options, social conditions, and external influences. The emergence of ecotourism has created new linkages between wildlife and livelihoods, as well as new decision-making dynamics, as communities form alliances with external organizations (Gadd 2005). As new land-use strategies arise, we can expect the terms and conditions of new land-use policies to shape residents' perceptions and values regarding ecosystem services, economic benefits, and management options. 
We saw divergences in five communities' perceptions of forage and livestock scarcity. Also, each community exhibited different sets of values regarding ecological and economic benefits resulting from the formation of conservation areas with external partner organizations. In addition, the traditional forms of social capital that have fostered resilience in pastoralist systems can vary, and with them we believe the capacity for resource governance may vary as well. The divergences in perceptions, values, and levels of social capital seen in these communities paint a cautionary picture for conservation plans that attempt to apply a single strategy or system of rules across numerous communities. Even among culturally similar communities, no single trajectory for sustainable resource use may fit all. Communities and external partners must recognize each other's values and perceptions to ensure that objectives and trajectories of change are ultimately sustainable.

Responses to this article can be read online at: http://www.ecologyandsociety.org/issues/responses. $\mathrm{php} / 6753$

\section{Acknowledgments:}

We are grateful for support from the Princeton Institute for International and Regional Studies, the Princeton Environmental Institute, and the Mamdouha Bobst Center for Peace and Justice. We thank the residents, leadership, and numerous translators from Il Motiok, Kijabe, Koija, Musul, and Tiemamut Group Ranches for their invaluable cooperation and facilitation of this study. We also thank the administrators and staff of Mpala Research Centre, Laikipia Wildlife Forum, African Wildlife Forum, Loisaba Wilderness, Lemarti's Camp, Ol Jogi Ltd., and Ol Lentille Lodge for providing assistance and useful information. We are grateful to two anonymous reviewers whose feedback helped improve the manuscript. This research was authorized by the Government of Kenya (Permit MOST/13/001/37C831/2).

\section{LITERATURE CITED}

Adams, W. M., D. Brockington, J. Dyson, and B. Vira. 2003. Managing tragedies: understanding conflict over common pool resources. Science 302:1915-1916. http://dx.doi.org/10.1126/ science. 1087771

Agrawal, A. 2007. Forests, governance, and sustainability: common property theory and its contributions. International Journal of the Commons 1:111-136.

Angassa, A., and G. Oba. 2008. Herder perceptions on impacts of range enclosures, crop farming, fire ban and bush encroachment on the rangelands of Borana, southern Ethiopia. Human Ecology 36:201-215. http://dx.doi.org/10.1007/s10745-007-9156$\underline{z}$

Baars, R. M. T., and S. M. Aptidon. 2002. Pastoralists' perceptions of rangeland degradation in Eastern Ethiopia. Nomadic Peoples 6:144-157. http://dx.doi.org/10.3167/082279402782311112
Baird, T. D., P. W. Leslie, and J. T. McCabe. 2009. The effect of wildlife conservation on local perceptions of risk and behavioral response. Human Ecology 37:463-474. http://dx.doi.org/10.1007/ s10745-009-9264-Z

Ballet, J., N. Sirven, and M. Requiers-Desjardins. 2007. Social capital and natural resource management: a critical perspective. Journal of Environmental Development 16:355-372. http://dx.doi. org/10.1177/1070496507310740

Behnke, R., and I. Scoones. 1993. Rethinking range ecology: implications for rangeland management in Africa. Pages 153-172 in R. Behnke, I. Scoones, and C. Kerven, editors. Range ecology at disequilibrium: new models of natural variability and pastoral adaptation in African savannas. Overseas Development Institute, Nottingham, England.

Bennett, E. M., G. D. Peterson, and L. J. Gordon. 2009. Understanding relationships among multiple ecosystem services. Ecology Letters 12:1394-1404. http://dx.doi.org/10.1111/ j.1461-0248.2009.01387.x

Berkes, F., J. Colding, and C. Folke. 2000. Rediscovery of traditional ecological knowledge as adaptive management. Ecological Applications 10:1251-1262. http://dx.doi.org/10.1890/1051-0761 (2000)010[1251:ROTEKA]2.0.CO;2

Berkes, F., and N. J. Turner. 2006. Knowledge, learning and the evolution of conservation practice for social-ecological system resilience. Human Ecology 34:479-494. http://dx.doi.org/10.1007/ s10745-006-9008-2

Bullock, J. M., J. Aronson, A. C. Newton, R. F. Pywell, and J. M. Rey-Benayas. 2011. Restoration of ecosystem services and biodiversity: conflicts and opportunities. Trends in Ecology \& Evolution 26:541-549. http://dx.doi.org/10.1016/j.tree.2011.06.011

Catley, A., J. Lind, and I. Scoones. 2013. Development at the margins: pastoralism in the Horn of Africa. Pages 1-26 in A. Catley, J. Lind, and I. Scoones, editors. Pastoralism and development in Africa: dynamic change at the margins. Routledge, New York, New York, USA.

Cavender-Bares, J., S. Polasky, E. King, and P. Balvanera. 2014. A sustainability framework for assessing trade-offs in ecosystem services. Ecology and Society, in press.

Center for Natural Resource Information Technology (CNRIT). 2011. Global Livestock Early Warning System: East Africa, Kenya - Laikipia: KE-LA-MPA-01, KE-LA-MPA-03. CNRIT, Texas A\&M University, College Station, Texas, USA. [online] URL: http://glews.tamu.edu/eastafrica

Cousins, B., M. T. Hoffman, N. Allsopp, and R. F. Rohde. 2007. A synthesis of sociological and biological perspectives on sustainable land use in Namaqualand. Journal of Arid Environments 70:834-846. http://dx.doi.org/10.1016/j.jaridenv.2007.04.002

Davies, J., and R. Bennett. 2007. Livelihood adaptation to risk: constraints and opportunities for pastoral development in Ethiopia's Afar region. Journal of Development Studies 43:490-511. http://dx.doi.org/10.1080/00220380701204422

Díaz, S., F. Quétier, D. M. Cáceres, S. F. Trainor, N. PérezHarguindeguy, M. S. Bret-Harte, B. Finegan, M. Peña-Claros, 
and L. Poorter. 2011. Linking functional diversity and social actor strategies in a framework for interdisciplinary analysis of nature's benefits to society. Proceedings of the National Academy of Sciences of the United States America 108:895-902. http://dx.doi. org/10.1073/pnas.1017993108

Dietz, T., E. Ostrom, and P. C. Stern. 2003. The struggle to govern the commons. Science 302:1907-1912. http://dx.doi.org/10.1126/ $\underline{\text { science. } 1091015}$

Ellis, J. E. 1995. Climate variability and complex ecosystem dynamics: implications for pastoral development. Pages 37-46 in

I. Scoones, editor. Living with uncertainty: new directions in pastoral development in Africa. International Institute for Environment and Development, London, UK.

Ellis, J. E., and D. M. Swift. 1988. Stability of African pastoral ecosystems: alternate paradigms and implications for development. Journal of Range Management 41:450-459. http:// dx.doi.org/10.2307/3899515

Franz, T. E. 2010. Characterizing dryland surface hydrological dynamics using ecohydrological modeling and geophysical observations. Dissertation. Princeton University, Princeton, New Jersey, USA.

Franz, T. E., K. K. Caylor, J. M. Nordbotten, R. I. RodríguezItubre, and M. A. Celia. 2010. An ecohydrological approach to predicting regional woody species distribution patterns in dryland ecosystems. Advances in Water Resources 33:215-230. http://dx. doi.org/10.1016/j.advwatres.2009.12.003

Fratkin, E. 1986. Stability and resilience in East African pastoralism: the Rendille and the Ariaal of northern Kenya. Human Ecology 14:269-286. http://dx.doi.org/10.1007/BF00889031

Fratkin, E. 1997. Pastoralism: governance and development issues. Annual Review of Anthropology 26:235-261. http://dx.doi. org/10.1146/annurev.anthro.26.1.235

Fratkin, E. 2001. East African pastoralism in transition: Maasai, Boran, and Rendille cases. African Studies Review 44:1-25. http:// dx.doi.org/10.2307/525591

Gadd, M. E. 2005. Conservation outside of parks: attitudes of local people in Laikipia, Kenya. Environmental Conservation 32:50-63. http://dx.doi.org/10.1017/S0376892905001918

Galvin, K. A. 1992. Nutritional ecology of pastoralists in dry tropical Africa. American Journal of Human Biology 4:209-221. http://dx.doi.org/10.1002/ajhb.1310040206

Galvin, K. A. 2008. Responses of pastoralists to land fragmentation: social capital, connectivity and resilience. Pages 369-389 in K. A. Galvin, R. S. Reid, R. H. Behnke, and N. T. Hobbs, editors. Fragmentation in semi-arid and arid landscapes: consequences for human and natural landscapes. Springer, Dordrecht, The Netherlands. http://dx.doi.org/10.1007/978-1-4020-4906-4 15

Goldman, M. J., and F. Riosmena. 2013. Adaptive capacity in Tanzanian Maasailand: changing strategies to cope with drought in fragmented landscapes. Global Environmental Change 23:588-597. http://dx.doi.org/10.1016/j.gloenvcha.2013.02.010

Henrich, J., R. Boyd, S. Bowles, C. Camerer, E. Fehr, H. Gintis, R. McElreath, M. Alvard, A. Barr, J. Ensminger, N. S. Henrich,
K. Hill, F. Gil-White, M. Gurven, F. W. Marlowe, J. Q. Patton, and D. Tracer. 2005. "Economic man" in cross-cultural perspective: behavioral experiments in 15 small-scale societies. Behavioral and Brain Sciences 28:795-815. http://dx.doi. org/10.1017/S0140525X05000142

Herren, U. J. 1991. "Droughts have different tails": response to crises in Mukogodo Division, North Central Kenya, 1950s-1980s. Disasters 15:93-107. http://dx.doi.org/10.1111/j.1467-7717.1991. $\underline{\text { tb00438.x }}$

Hicks, C. C., N. A. J. Graham, and J. E. Cinner. 2013. Synergies and tradeoffs in how managers, scientists, and fishers value coral reef ecosystem services. Global Environmental Change 23:1444-1453. http://dx.doi.org/10.1016/j.gloenvcha.2013.07.028

Homann, S., B. Rischkowsky, J. Steinbach, M. Kirk, and E. Mathias. 2008. Towards endogenous livestock development: Borana pastoralists' responses to environmental and institutional changes. Human Ecology 36:503-520. http://dx.doi.org/10.1007/ s10745-008-9180-7

Jones, S. 2005. Community-based ecotourism: the significance of social capital. Annals of Tourism Research 32:303-324. http://dx. doi.org/10.1016/j.annals.2004.06.007

Kahneman, D. 2003. Maps of bounded rationality: psychology for behavioral economics. American Economic Review 93:1449-1475. http://dx.doi.org/10.1257/000282803322655392

Kaitho, R., J. Ndungu, J. Stuth, G. Kariuki, and A. Jama. 2006. Analysis of the November 2005-April 2006 drought in Kenya. Global Livestock Collaborative Research Support Program (GLCRSP) Research Brief 06-02-LINKS. University of California, Davis, California, USA.

Kaye-Zwiebel, E. 2011. Development aid and community public goods provision: a study of pastoralist communities in Kenya. Dissertation. Princeton University, Princeton, New Jersey, USA.

Kenya Land Conservation Trust. 2009. Ecotourism in northern Kenya policy brief. USAID Regional Enhanced Livelihoods in Pastoral Areas, Nairobi, Kenya.

Kirkbride, M., and R. Grahn. 2008. Survival of the fittest: pastoralism and climate change in East Africa. Oxfam Briefing Paper No. 116. Oxfam International, Oxford, UK.

Lamarque, P., U. Tappeiner, C. Turner, M. Steinbacher, R. D. Bardgett, U. Szukics, M. Schermer, and S. Lavorel. 2011. Stakeholder perceptions of grassland ecosystem services in relation to knowledge on soil fertility and biodiversity. Regional Environmental Change 11:791-804. http://dx.doi.org/10.1007/ $\underline{\mathrm{s} 10113-011-0214-0}$

Lesorogol, C. K. 2008. Contesting the commons: privatizing pastoral lands in Kenya. University of Michigan Press, Ann Arbor, Michigan, USA.

Letai, J., and J. Lind. 2013. Squeezed from all sides: changing resource tenure and pastoralist innovation on the Laikipia Plateau, Kenya. Pages 164-176 in A. Catley, J. Lind, and I. Scoones, editors. Pastoralism and development in Africa: dynamic change at the margins. Routledge, New York, New York, USA.

Little, P. D. 2013. Reflections on the future of pastoralism in the Horn of Africa. Pages 243-249 in A. Catley, J. Lind, and I. 
Scoones, editors. Pastoralism and development in Africa: dynamic change at the margins. Routledge, New York, New York, USA.

Ludwig, J. A., B. P. Wilcox, D. D. Breshears, D. J. Tongway, and A. C. Imeson. 2005. Vegetation patches and runoff-erosion as interacting ecohydrological processes in semiarid landscapes. Ecology 86:288-297. http://dx.doi.org/10.1890/03-0569

McCabe, J. T. 1994. Mobility and land use among African pastoralists: old conceptual problems and new interpretations. Pages 69-90 in E. M. Fratkin, K. A. Galvin, and E. A. Roth, editors. African pastoralist systems: an integrated approach. Lynne Reinner, Boulder, Colorado, USA.

McPeak, J. 2005. Individual and collective rationality in pastoral production: evidence from northern Kenya. Human Ecology 33:171-197. http://dx.doi.org/10.1007/s10745-005-2431-Y

McPeak, J. G. 2006. Confronting the risk of asset loss: what role do livestock transfers in northern Kenya play? Journal of Development Economics 81:415-437. http://dx.doi.org/10.1016/j. jdeveco.2005.06.010

McShane, T. O., P. D. Hirsch, T. C. Trung, A. N. Songorwa, A. Kinzig, B. Monteferri, D. Mutekanga, H. V. Thang, J. L. Dammert, M. Pulgar-Vidal, M. Welch-Devine, J. Peter Brosius, P. Coppolillo, and S. O'Connor. 2011. Hard choices: making trade-offs between biodiversity conservation and human wellbeing. Biological Conservation 144:966-972. http://dx.doi. org/10.1016/j.biocon.2010.04.038

Muthiani, E. N., J. T. Njoka, and G. K. Gitau. 2011. Partnership challenges of Community Wildlife Sanctuaries in Laikipia County, Kenya. KASAL Program Conference, Kenya Agricultural Research Institute Headquarters (9-12 August, Nairobi, Kenya). University of Nairobi, Nairobi, Kenya. [online] URL: http:// erepository.uonbi.ac.ke/handle/11295/11544

Niamir-Fuller, M. 1998. The resilience of pastoral herding in Sahelian Africa. Pages 250-284 in F. Berkes and C. Folke, editors. Linking social and ecological systems: management practices and social mechanisms for building resilience. Cambridge University Press, New York, New York, USA.

Notenbaert, A. M. O., J. Davies, J. De Leeuw, M. Said, M. Herrero, P. Manzano, M. Waithaka, A. Aboud, and S. Omondi. 2012. Policies in support of pastoralism and biodiversity in the heterogeneous drylands of East Africa. Pastoralism: Research, Policy and Practice 2:14. http://dx.doi.org/10.1186/2041-7136-2-14

Notenbaert, A., M. Herrero, R. L. Kruska, L. You, S. Wood, P. E. Thornton, and A. Omolo. 2009. Classifying livestock production systems for targeting agricultural research and development in a rapidly changing world. International Livestock Research Institute (ILRI) Discussion Paper 19. ILRI, Nairobi, Kenya.

Oguge, N. 2005. Monitoring and evaluation of community-based natural resource management programmes: biological databases and range conditions in Koija, Tiemamut and Kijabe Group Ranches of Laikipia District. Final report. African Wildlife Foundation, Nairobi, Kenya.

Ostrom, E. 1990a. Analyzing long-enduring, self-organized and self-governed CPRs. Pages 58-102 in E. Ostrom, editor. Governing the commons: the evolution of institutions for collective action. Cambridge University Press, Cambridge, UK. http://dx.doi. org/10.1017/CBO9780511807763.005

Ostrom, E. 1990b. Governing the commons: the evolution of institutions for collective action. Cambridge University Press, Cambridge, UK. http://dx.doi.org/10.1017/CBO9780511807763

Potanski, T. 1999. Mutual assistance among the Ngorongoro Maasai. Pages 199-217 in D. M. Anderson and V. Broch-Due, editors. The poor are not us: poverty and pastoralism in eastern Africa. Ohio University Press, Athens, Ohio.

Pretty, J. 2003. Social capital and the collective management of resources. Science 302:1912-1914. http://dx.doi.org/10.1126/ science. 1090847

Quinn, C. H., M. Huby, H. Kiwasila, and J. C. Lovett. 2003. Local perceptions of risk to livelihood in semi-arid Tanzania. Journal of Environmental Management 68:111-119. http://dx.doi. org/10.1016/S0301-4797(03)00013-6

Reid, R. S., D. Nkedianye, M. Y. Said, D. Kaelo, M. Neselle, O. Makui, L. Onetu, S. Kiruswa, N. O. Kamuaro, P. Kristjanson, J. Ogutu, S. B. BurnSilver, M. J. Goldman, R. B. Boone, K. A. Galvin, N. M. Dickson, and W. C. Clark. 2009. Evolution of models to support community and policy action with science: balancing pastoral livelihoods and wildlife conservation in savannas of East Africa. Proceedings of the National Academy of Sciences of the United States. http://dx.doi.org/10.1073/ pnas.0900313106

Rietkerk, M., M. C. Boerlijst, F. van Langevelde, R. HilleRisLambers, J. van de Koppel, L. Kumar, H. H. T. Prins, and A. M. de Roos. 2002. Self-organization of vegetation in arid ecosystems. American Naturalist 160:524-530. http://dx.doi. org/10.1086/342078

Rodríguez, J. P., T. D. Beard, Jr., E. M. Bennett, G. S. Cumming, S. Cork, J. Agard, A. P. Dobson, and G. D. Peterson. 2006. Tradeoffs across space, time, and ecosystem services. Ecology and Society 11(1): 28. [online] URL: http://www.ecologyandsociety. org/vol11/iss1/art28/

Runge, C. F. 1986. Common property and collective action in economic development. World Development 14:623-635. http:// dx.doi.org/10.1016/0305-750X(86)90128-2

Rutten, M. 2002. Parks beyond parks: genuine community-based wildlife eco-tourism or just another loss of land for Maasai pastoralists in Kenya? IIED Issue Paper No. 111. International Institute for Environment and Development, London, UK.

Sanginga, P. C., R. N. Kamugisha, and A. M. Martin. 2007. The dynamics of social capital and conflict management in multiple resource regimes: a case of the southwestern highlands of Uganda. Ecology and Society 12(1): 6. [online] URL: http://www. ecologyandsociety.org/vol12/iss1/art6/

Santos, F. C., and J. M. Pacheco. 2011. Risk of collective failure provides an escape from the tragedy of the commons. Proceedings of the National Academy of Sciences of the United States of America 108:10421-10425. http://dx.doi.org/10.1073/pnas.1015648108

SAS Institute. 2012. JMP Pro 10.0.0 statistical software. SAS Institute, Cary, North Carolina, USA. 
Selemani, I. S., L. O. Eik, Ø. Holand, T. Ådnøy, E. Mtengeti, and D. Mushi. 2012. The role of indigenous knowledge and perceptions of pastoral communities on traditional grazing management in north-western Tanzania. African Journal of Agricultural Research 7:5537-5547.

Steins, N. A., and V. M. Edwards. 1999. Platforms for collective action in multiple-use common-pool resources. Agriculture and Human Values 16:241-255. http://dx.doi.org/10.1023/A:1007591401621

Tache, B. 2013. Rangeland enclosures in southern Oromo, Ethopia: an innovative response or the erosion of common property resources? Pages 37-46 in A. Catley, J. Lind, and I. Scoones, editors. Pastoralism and development in Africa: dynamic change at the margins. Routledge, New York, New York, USA.

Tallis, H., P. Kareiva, M. Marvier, and A. Chang. 2008. An ecosystem services framework to support both practical conservation and economic development. Proceedings of the National Academy of Sciences of the United States of America 105:9457-9464. http://dx.doi.org/10.1073/pnas.0705797105

Thébaud, B., and S. Batterbury. 2001. Sahel pastoralists: opportunism, struggle, conflict and negotiation. A case study from eastern Niger. Global Environmental Change 11:69-78. http:// dx.doi.org/10.1016/S0959-3780(00)00046-7

Thornton, P. K., P. G. Jones, T. Owiyo, R. L. Kruska, M. Herrero, P. Kristjanson, A. Notenbaert, N. Bekele, and A. Omolo. 2006. Mapping climate vulnerability and poverty in Africa. International Livestock Research Institute, Nairobi, Kenya. 
Appendix 1. Details of methods for census, surveys, experimental games, and analyses.

Community engagement prior to census, surveys, and experimental games:

Prior to initiation of the study, we advertised and held public meetings in each community to explain the nature of the research, and seek permission from the communities to travel from household to household conducting surveys. Establishing a rapport with residents and community leadership was facilitated due to one author's (King) history of conducting research in the area since 2001. All communities cordially welcomed the research. We consulted with and sought permission from community leadership again prior to holding rounds of experimental economic games.

Census and survey enumerator selection, training and translation:

To conduct census and questionnaire surveys of households, we employed thirteen community residents (8 male, 5 female) who were fluent in English and Maasai. Candidates were identified by community leaders or referred by word-of-mouth. Each enumerator worked in his or her home community, and was offered employment for the duration of the field component of the study. Since the authors do not speak Maasai, we used direct instruction in English as well as peer-to-peer learning in order to train local enumerators. We explained in English the meaning, purpose, and intent of each question, then engaged the enumerators to discuss the best ways to translate the questions into Maasai, in efforts to reduce the differences in the way each enumerator translated the questions. The generality of the wording of questions relating to ecological variables was intentional. We did not wish to impose our specific and foreign concepts of what constitutes land health, livestock health, or benefits to wildlife. In our experience, and in accordance with extensive anthropological research, herders tend to have an intimate understanding of land health, livestock health, and the relationship between the two. Also, since the study area is home to diverse wildlife species, pastoralists demonstrate strong knowledge of wildlife habitat preferences, seasonal abundance, watering needs, etc. Thus while some individuals interviewed may have held slightly different conceptions of what these terms mean, we found that nobody was confused by the questions, and everyone did seem have some clear idea of what "land health" meant to them.

On most questions, possible responses were constrained to yes/no, a few choices (e.g., less than, greater than, or about equal), or a numerical response (e.g., 3 days). We relied on the enumerators to appropriately convey the questions to respondents while conducting surveys, and to align responses with the possible choices, asking for clarification if necessary. While this approach curtailed the nuance we could capture in questionnaires, we felt it was important to reduce the opportunity for translation ambiguity from the respondent to the recorded data. Given that each enumerator only worked within one community, we were particularly concerned about generating community-to-community bias and inconsistencies in the way responses would be translated back to English.

Household census and surveys:

Enumerators conducted exhaustive census of all residential compounds in each community, which were considered the household unit in this study. Enumerators systematically traveled through areas where compounds were scattered, approaching each compound, explaining the nature of the census, and asking if the residents were willing to participate. Every compound was cooperative. Since livestock herd size and family size were self-reported, 
inaccurate reportings were possible. However, enumerators were also community members and thus familiar with the general livestock wealth and family size of each compound. They were able to flag any questionable numbers, and in those cases, the reported census numbers were excluded from analysis.

A stratified subsample of all households was selected for additional questionnaire surveys. The questionnaires were designed as part of a larger, more complex study of social capital, governance, external relations, and natural resource management (Kaye-Zwiebel 2011), so they contained several other question topics that are not considered or presented in this report. For most questions, one adult per household was interviewed. There was a subset of questions, however, for which one male and one female were interviewed whenever both were available when visiting a household. Only one of those questions was analyzed in this report, Survey Question \#7 regarding subdivision. Completed surveys were scrutinized for missing data and indicators of faulty data recording. For some households, surveys were not fully completed or had missing responses for some questions. Such households were included in the analyses of the questions that were correctly recorded in their survey. As a result, the sample sizes for some questions are smaller than the total number of households visited, which were for each community: $\mathrm{C} 1=28, \mathrm{C} 2=51, \mathrm{C} 3=32, \mathrm{C} 4=42, \mathrm{C} 5=38$.

C1 Tiemamut $\mathrm{n}=28$

C2 Koija n-51

C3 Il Motiok $n=32$

C4 Kijabe $\mathrm{n}=42$

C5 Musul $\mathrm{n}=38$

\section{English text of survey auestions analyzed in this study:}

1. In terms of what the land can support, is the total number of animals living on your Group Ranch:

1 more than

1 about equal to

1 less than

the number that the land can support?

2. In terms of meeting your family's needs, is the number of animals you own:

1 more than

1 about equal to

1 less than

what you need?

3. If you think the conservation zone is a good idea, do you think it is good because:

1Yes 1No We get a monetary reward if we keep it

1Yes 1No It makes our land healthier

1Yes 1No It makes our herds healthier

1Yes 1No It helps wild animals

1Yes 1No It helps water points retain water 
1Yes 1No It provides employment

Are there other reasons that the conservation zone is good?

$(n=6$, not analyzed $)$

4. How many days in the past month did people in this manyatta eat food that was given or lent to you? days

5. Does anyone in this manyatta own animals that are living with another family in order to help that family? 1Yes 1 No

6. In the past 3 years, has anyone in this manyatta been fined? 1Yes 1No For what reason(s)? _ (tabulated by category, not analyzed)

7. In southern Maasailand, there are group ranches that have subdivided, so that families own smaller pieces of land privately. Would doing that here be:

1 mostly good

1 in between (translated as mixed, tolerable, ok)

1 mostly bad

\section{Experimental Games}

We invited community members to participate in this game on a volunteer basis. At two locations in each community, the date, time, and nature of the game was advertised through the Group Ranch leadership, and through community liaisons working with other organizations. We announced that a simple game would be played, with a chance to win money, and that all adults from the community arriving within 45 minutes of the start time would be able to participate. Players were assigned numbers in the order of their arrival; those with odd numbers would be proposers and those with even numbers would be responders. The even and odd numbers were randomly paired and recorded on a list, but the players themselves did not know the identity of their paired partner. Once participants were assembled, the game was explained and illustrated with a few demonstration rounds until all participants acknowledged that they understood the game. Players also understood that they would receive cash payouts, at the rate of KSh 10 per goat in the scenario, according to their offers and whether the offer was accepted. Thus each team would either share or lose KSh 200 (US\$2.50, or approximately one day's basic labor wage).

In the execution of the game, each of the "proposers" was called by number, taken aside and asked in private what they would offer their anonymous partner. Their offer was recorded next to their number, and they were asked to wait in a separate location (under a different tree) from the participants who had not yet played. Then we called each of the respondents by number, took them aside, and told them the offer made by their anonymously paired partner. They responded to accept or reject the offer, and their response recorded. After all rounds were played, we told each proposer whether their offer was accepted, and if so, they were paid. Then we paid each responder their offered share, unless they rejected, in which case they received no payment. We played the game at two locations on separate days in each community, and there were a total of 280 pairs of participants across all communities.

\section{$\underline{\text { Demographics }}$}


From the census data, we calculated active adult male equivalents (AAME), modified from Lesorogol (2008), where adult males/warriors $=1$, adult females $=.86$, children of any age $=0.85$ AAME. We converted household and community livestock holdings to tropical livestock units (TLU), following Galvin (1992), where cattle $=1$, goats or sheep $=0.10$, camels $=2.5$ TLU. Empirical data of forage productivity in the five communities were unavailable, yet we wanted some corroboration of our qualitative observations that forage availability did not vary dramatically among communities. We used three sources of information to support observations of general similarity across communities. First, the Global Livestock Early Warning System (GLEWS) uses vegetation transects, NDVI and NOAA weather data, and a forage production model to generate co-kriged maps of average forage standing crop for the study region. GLEWS outputs show similar average standing forage of 980 to $1055 \mathrm{~kg} / \mathrm{ha}$ for the study communities (CNRIT 2011). In rapid assessments of grazing condition in three of the communities (C1, C2, and C4), conditions were fair to poor in all land use zones in each community (Oguge 2005). Lastly, a 2007 herding study in three communities (C1, C2, and C3) showed comparable grass densities when averaged across livestock grazing routes in each community (E.G. King and D. I. Rubenstein, unpublished data). 
Table A1.1 Summary of statistical analyses performed. Variables in italics are continuous variables; all other variables are categorical.

\begin{tabular}{|c|c|c|c|c|}
\hline Dependent variable & $\begin{array}{c}\text { Explanatory } \\
\text { variable }\end{array}$ & $\begin{array}{l}\text { Source } \\
\text { of Data }\end{array}$ & $\begin{array}{c}\text { Statistical } \\
\text { Method } \\
\end{array}$ & $\begin{array}{c}\text { Sample Size } \\
(\mathrm{C} 1, \mathrm{C} 2, \mathrm{C} 3, \mathrm{C} 4, \mathrm{C} 5) \\
\end{array}$ \\
\hline \multicolumn{5}{|c|}{ Perceptions of Ecosystem Services } \\
\hline $\begin{array}{l}\text { a) Perception of forage } \\
\text { sufficiency }(y / n) \\
\text { b) Perception of herd } \\
\text { sufficiency }(y / n)\end{array}$ & Community $(\mathrm{n}=5)$ & $\begin{array}{l}\text { a) Survey } \\
\text { question \#1 } \\
\text { b) Survey } \\
\text { question \#2 }\end{array}$ & $\begin{array}{l}\text { Chi-square } \\
\text { contingency }\end{array}$ & $\begin{array}{l}\mathrm{N}=178 \mathrm{HHs} \\
(25,49,30,40,34)\end{array}$ \\
\hline $\begin{array}{l}\text { a) Perception of forage } \\
\text { sufficiency }(y / n) \\
\text { b) Perception of herd } \\
\text { sufficiency }(y / n)\end{array}$ & $\begin{array}{l}\text { 1) Household wealth } \\
\text { (TLU) } \\
\text { 2) Per capita wealth } \\
\text { (TLU/AAME) } \\
\text { 3) respondent age (yr) }\end{array}$ & $\begin{array}{l}\text { Census data, } \\
\text { a) Survey } \\
\text { question \#1 } \\
\text { b) Survey } \\
\text { question \#2 }\end{array}$ & $\begin{array}{l}\text { Logistic } \\
\text { regression }\end{array}$ & $\begin{array}{l}\mathrm{N}=177 \mathrm{HHs} \text { across } \\
\text { all communities }\end{array}$ \\
\hline $\begin{array}{l}\text { Perception of forage } \\
\text { sufficiency }(y / n)\end{array}$ & $\begin{array}{l}\text { Perception of herd } \\
\text { sufficiency }\end{array}$ & $\begin{array}{l}\text { Survey } \\
\text { questions \#1 } \\
\text { and \#2 }\end{array}$ & $\begin{array}{l}\text { Chi-square } \\
\text { contingency }\end{array}$ & $\begin{array}{l}\mathrm{N}=177 \mathrm{HHs} \text { across } \\
\text { all communities }\end{array}$ \\
\hline $\begin{array}{l}\text { Proportion perceiving } \\
\text { forage sufficiency }\end{array}$ & $\begin{array}{l}\text { Grazing availability } \\
(\text { ha/TLU) }\end{array}$ & $\begin{array}{l}\text { Census data; } \\
\text { question \#1 }\end{array}$ & $\begin{array}{l}\text { Linear } \\
\text { regression }\end{array}$ & $\mathrm{N}=5$ communities \\
\hline $\begin{array}{l}\text { Benefits from } \\
\text { conservation areas: (y/n) } \\
\text { a) helps land health } \\
\text { b) helps herd health } \\
\text { c) helps wildlife } \\
\text { d) monetary reward } \\
\text { e) provides employment }\end{array}$ & $\begin{array}{l}\text { 1) Community }(n=4) \\
\text { 2) respondent age }(y r)\end{array}$ & $\begin{array}{l}\text { Survey } \\
\text { question \#3 } \\
\text { parts a-e }\end{array}$ & $\begin{array}{l}\text { 1) Chi-square } \\
\text { contingency } \\
\text { 2) Logistic } \\
\text { regression }\end{array}$ & $\begin{array}{l}\mathrm{N}=157 \mathrm{HHs} \\
(24,47,30,39,0)\end{array}$ \\
\hline $\begin{array}{l}\text { Perception of benefits to } \\
\text { herd health }(y / n)\end{array}$ & $\begin{array}{l}\text { Perception benefits } \\
\text { from employment }\end{array}$ & $\begin{array}{l}\text { Survey } \\
\text { questions \#3b } \\
\text { and \#3e }\end{array}$ & $\begin{array}{l}\text { Chi-square } \\
\text { contingency }\end{array}$ & $\begin{array}{l}\mathrm{N}=177 \mathrm{HHs} \text { across } \\
\text { all communities }\end{array}$ \\
\hline \multicolumn{5}{|l|}{ Assessments of Social Capital } \\
\hline $\begin{array}{l}\text { Food sharing (days/month } \\
\text { received) }\end{array}$ & Community $(\mathrm{n}=5)$ & $\begin{array}{l}\text { Survey } \\
\text { question \#4 }\end{array}$ & ANOVA & $\begin{array}{l}\mathrm{N}=147 \mathrm{HHs} \\
(28,21,29,35,34)\end{array}$ \\
\hline $\begin{array}{l}\text { HH currently lending } \\
\text { stock to other } \mathrm{HH}(\mathrm{y} / \mathrm{n})\end{array}$ & Community $(\mathrm{n}=5)$ & $\begin{array}{l}\text { Survey } \\
\text { question \#5 }\end{array}$ & $\begin{array}{l}\text { Chi-square } \\
\text { contingency }\end{array}$ & $\begin{array}{l}\mathrm{N}=154 \mathrm{HHs} \\
(27,29,30,35,33)\end{array}$ \\
\hline $\begin{array}{l}\text { HH member fined in the } \\
\text { last } 3 \text { years }(y / n)\end{array}$ & Community $(\mathrm{n}=5)$ & $\begin{array}{l}\text { Survey } \\
\text { question \#6 }\end{array}$ & $\begin{array}{l}\text { Chi-square } \\
\text { contingency }\end{array}$ & $\begin{array}{l}\mathrm{N}=155 \mathrm{HHs} \\
(27,29,30,35,34)\end{array}$ \\
\hline $\begin{array}{l}\text { Ultimatum Game offers } \\
\text { (\% of total goats) }\end{array}$ & Community $(\mathrm{n}=5)$ & $\begin{array}{l}\text { Ultimatum } \\
\text { Game }\end{array}$ & None & $\begin{array}{l}\mathrm{N}=280 \text { 'proposers' } \\
(45,66,72,55,42)\end{array}$ \\
\hline $\begin{array}{l}\text { Land subdivision among } \\
\text { families would be: } \\
\text { (good/bad/in-between) }\end{array}$ & Community $(\mathrm{n}=5)$ & $\begin{array}{l}\text { Survey } \\
\text { question \#7 }\end{array}$ & $\begin{array}{l}\text { Chi-square } \\
\text { contingency }\end{array}$ & $\begin{array}{l}\mathrm{N}=247 ; 1 \text { male and } 1 \\
\text { female per } \mathrm{HH} \text { when } \\
\text { available } \\
(60,38,34,56,59)\end{array}$ \\
\hline
\end{tabular}

